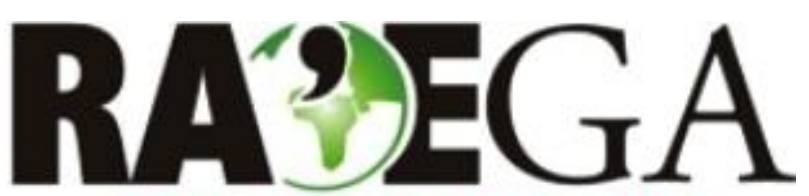

O ESPACCO GEOGRÁFICO EM ANÁLISE

\title{
REMOTE SENSING APPROACH TO QUANTIFY CARBON DIOXIDE EMISSIONS FROM SUGARCANE PRE- HARVEST BURNING
}

\section{ABORDAGEM DE SENSORIAMENTO REMOTO PARA QUANTIFICAR AS EMISSÕES DE DIÓXIDO DE CARBONO ASSOCIADAS À QUEIMADA PRÉ-COLHEITA DA CANA-DE-AÇÚCAR}

\author{
Guilherme Augusto Verola Mataveli ${ }^{1}$, Gabriel Pereira ${ }^{2}$, Elisabete Caria Moraes ${ }^{3}$ \\ e, Bruno Silva Oliveira ${ }^{4}$
}

\begin{abstract}
Biomass burning is a major disturbance agent for ecosystems and has an important role in climate and in the Earth system, mainly due to the release of greenhouse gases, such as $\mathrm{CO}_{2}$, into the atmosphere, being observed an increase in these emissions over the last decades caused by human action. However, some initiatives were and are being proposed to reduce greenhouse gases emissions from biomass burning, for example, the Green Ethanol Protocol, which proposes the end of sugarcane pre-harvest burning in São Paulo state (Brazil), therefore, it is important to quantify the effectiveness of these proposals. In this context, this study aims to quantify the reduction in $\mathrm{CO}_{2}$ emissions from sugarcane pre-harvest burning in São Paulo state between 2008 and 2014 using multiplatform orbital remote sensing data and the method based on Fire Radiative Power (FRP). Results show a significant decrease in the estimates obtained between 2008 and 2014; total annual $\mathrm{CO}_{2}$ emitted in 2014 was approximately $5.2 \%$ of annual emissions in 2008 , and $4.1 \%$ of total emissions in 2010 , when they were highest. Considering the results found, it was possible to conclude that Green Ethanol Protocol presents positive results in reducing emissions of $\mathrm{CO}_{2}$ associated with sugarcane pre-harvest burning in São Paulo state.
\end{abstract}

KEY-WORDS: Fires; biomass burning; greenhouse gases; Fire Radiative Power; Green Ethanol Protocol.

\section{RESUMO}

A queima de biomassa é um dos principais fatores de perturbação dos ecossistemas, além de ter importante papel no clima e no sistema terrestre devido principalmente à emissão de gases do efeito estufa, como o $\mathrm{CO}_{2}$, para a atmosfera, sendo que observa-se nos últimos anos um aumento dessas emissões causado pela ação antrópica. Entretanto, algumas iniciativas foram e estão sendo propostas para reduzir essas emissões, como o Protocolo Etanol Verde, que propõe a eliminação gradativa da queimada pré-colheita da cana-de-açúcar no estado de São Paulo (Brasil), tornando-se importante quantificar a efetividade dessas propostas. Nesse contexto, o presente estudo objetiva quantificar a redução nas emissões de $\mathrm{CO}_{2}$ associadas à queimada pré-colheita no estado de São Paulo entre 2008 e 2014 a partir do uso de dados provenientes de sensores remotos orbitais e do método baseado na Potência Radiativa do Fogo (FRP). Os resultados encontrados mostram uma diminuição significativa nas emissões entre 2008 e 2014, já que o total de $\mathrm{CO}_{2}$ emitido em 2014 foi 5,2\% do total emitido em 2008, e 4,1\% do total em 2010, quando as maiores estimativas foram encontradas. Considerando os resultados encontrados pode-se concluir que a adoção do Protocolo Etanol Verde apresenta efeitos positivos na diminuição das emissões associadas à queimada pré-colheita.

PALAVRAS-CHAVE: Queimadas; queima de biomassa; gases do efeito estufa; Potência Radiativa do Fogo; Protocolo Etanol Verde.

Recebido em: 05/06/2016

Aceito em: 06/06/2017

\footnotetext{
1 Universidade de SãoPaulo,USP, São Paulo/SP e-mail: mataveli@usp.br

2 Universidade Federal de São João del Rey, UFSJ,São João del Rey/MG, e-mail: pereira@ufsj.edu.br

3 Instituto Nacional de Pesquisas Espaciais, INPE, e-mail: bete@dsr.inpe.br

${ }^{4}$ Instituto Nacional de Pesquisas Espaciais, INPE, e-mail: bruno.so@dsr.inpe.br
} 


\section{INTRODUCTION}

Biomass burning includes the combustion of all types of organic materials, especially plants, and is considered one of the major disturbance factors for ecosystems (ICHOKU et al., 2008). Wildfires have influence over atmospheric chemistry and radiation budget, mainly due to the emission of large amounts of trace gases and aerosols into the atmosphere (KAISER et al., 2012).

The complete combustion of vegetated areas releases carbon dioxide $\left(\mathrm{CO}_{2}\right)$ and water vapor $\left(\mathrm{H}_{2} \mathrm{O}\right)$ to the atmosphere, according to Equation 1 (LEVINE, 1994):

$$
\mathrm{CH}_{2} \mathrm{O}+\mathrm{O}_{2} \longrightarrow \mathrm{CO}_{2}+\mathrm{H}_{2} \mathrm{O}
$$

where $\mathrm{CH}_{2} \mathrm{O}$ represents the average composition of biomass, and $\mathrm{O}_{2}$ is oxygen.

However, complete combustion is hardly reached in nature, therefore, it is usual to find different species of trace gases and aerosols emitted by biomass burning, such as carbon monoxide (CO), methane $\left(\mathrm{CH}_{4}\right)$, and Black Carbon (BC), which impacts air quality, weather, and climate variability (BURLING et al., 2010; ICHOKU and ELLISON, 2014). Moreover, according to Ichoku and Ellison (2014), open biomass burning is one of the main sources of trace gases and aerosols emissions to the atmosphere. Biomass burning is estimated to be responsible for $34 \%$ to $38 \%$ of global emissions of carbonaceous aerosols, for $40 \%$ of global emissions of BC, and accounts for $25 \%$ of global increase of $\mathrm{CO}_{2}$ in the atmosphere since pre-industrial times (FORSTER et al., 2007). Therefore, it is necessary to quantify these emissions to understand their impact over climate and over biosphere/atmosphere interaction (MOUILLOT et al., 2014).

The analysis of a dynamic and widespread phenomenon such as biomass burning is a challenge (ICHOKU et al., 2012). Studies related to emissions from biomass burning were conducted over many decades from small-scale experiments and in situ measurements (ANDREAE and MERLET, 2001).
However, due to the advances in remote sensing in the early decades, products derived from orbital remote sensing became the main source of data for studying biomass burning and emissions, once they provide a good spatial and temporal coverage of areas affected by fires (HANTSON et al., 2013).

Traditionally, emissions from biomass burning are estimated considering the relationship between burned biomass and the emission factors, as shown in Equation 2 (SEILER and CRUTZEN, 1980):

$$
M=E^{*} \mathrm{~B}_{B}
$$

where $M$ represents the mass emitted $(g), E$ is the emission factor $\left(\mathrm{g} \mathrm{kg}^{-1}\right)$, and $B_{B}$ represents the burned biomass (kg).

However, to estimate $B_{B}$ during the combustion process is complex and can introduce significant errors in the estimated emissions (ICHOKU and KAUFAMNN, 2005), and, therefore, several methods are proposed to estimate burned biomass (FREEBORN et al., 2008). Traditionally, burned biomass is estimated form Equation 3 (SEILER and CRUTZEN, 1980):

$$
B_{B}=B_{A} * B_{D} * C F
$$

where $B_{B}$ represents the burned biomass $(\mathrm{kg}), B_{A}$ is the burned area $\left(\mathrm{km}^{2}\right), B_{D}$ is the above ground biomass $\left(\mathrm{kg} \mathrm{km}^{2}\right)$, and CF represents the combustion factor.

According to Pereira et al. (2012), the use of Equation 3 to estimate $B_{B}$ is limited because CF (that represents the fraction of biomass actually burned) is specific for each vegetal species, and because there are uncertainties in the estimates of $B_{A}$ and $B_{D}$ derived from orbital sensors. These difficulties generated the interest in developing alternative methods to estimate $B_{B}$ (ANDREAE and MERLET, 2001).

Currently, one of the most widely used methods to develop emission inventories from biomass burning is based on Fire Radiative Power (FRP) (ROBERTS et al., 2005; WOOSTER et al., 
2005; FREEBORN et al., 2008; PEREIRA et al., 2016). This method, based on the assumption that the amount of energy emitted as electromagnetic radiation during the combustion process can be directly related to the amount of burned biomass (WOOSTER, 2002), enables to relate the total burned biomass with gases and aerosols emissions into the atmosphere (KAISER et al., 2012), and presents good correlation with estimates obtained with field measurements, resulting in better correlations than methods based on burned area (ROBERTS et al., 2005).

In Brazil, open biomass burning is mainly related to areas of agricultural expansion, such as the arc of deforestation (Amazon biome) and the East portion of Northeast region (Cerrado biome), and management of pasture areas for livestock (SHIMABUKURO et al., 2013). In addition to these areas of agricultural expansion and pasture management, sugarcane pre-harvest burning in South-Central Brazil, especially in São Paulo state, actively contributes to biomass burning nationally (FRANÇA et al., 2012). With the rapid expansion of sugarcane cultivation in South-Central Brazil during the last decade, especially after the year 2003, the practice of pre-harvest burning is being banned in São Paulo state due to its negative impacts over health and the environment (AGUIAR et al., 2011).

In this context, this study aims to quantify the reduction in $\mathrm{CO}_{2}$ emissions associated with sugarcane pre-harvest burning in São Paulo state between 2008 and 2014 using multiplatform orbital sensors data and the FRP based method. As will be shown below, the study began in 2008 because this is the first year that one of the active fire products used was available and ended in 2014 because in this year preharvest burning should end in mechanizable areas of the study area.

\section{MATERIALS AND METHODS 2.1 STUDY AREA}

Agriculture represents a large share of Brazilian economy, once Brazil is the world leader in growing and exporting many agricultural products, such as sugarcane and soybeans (RUDORFF et al., 2010). Considering sugarcane, the state of São Paulo (Figure 1) is the main national producer, cultivating an area of approximately 5.5 million hectares (ha) that represents approximately $50 \%$ of national production (CANASAT, 2016).

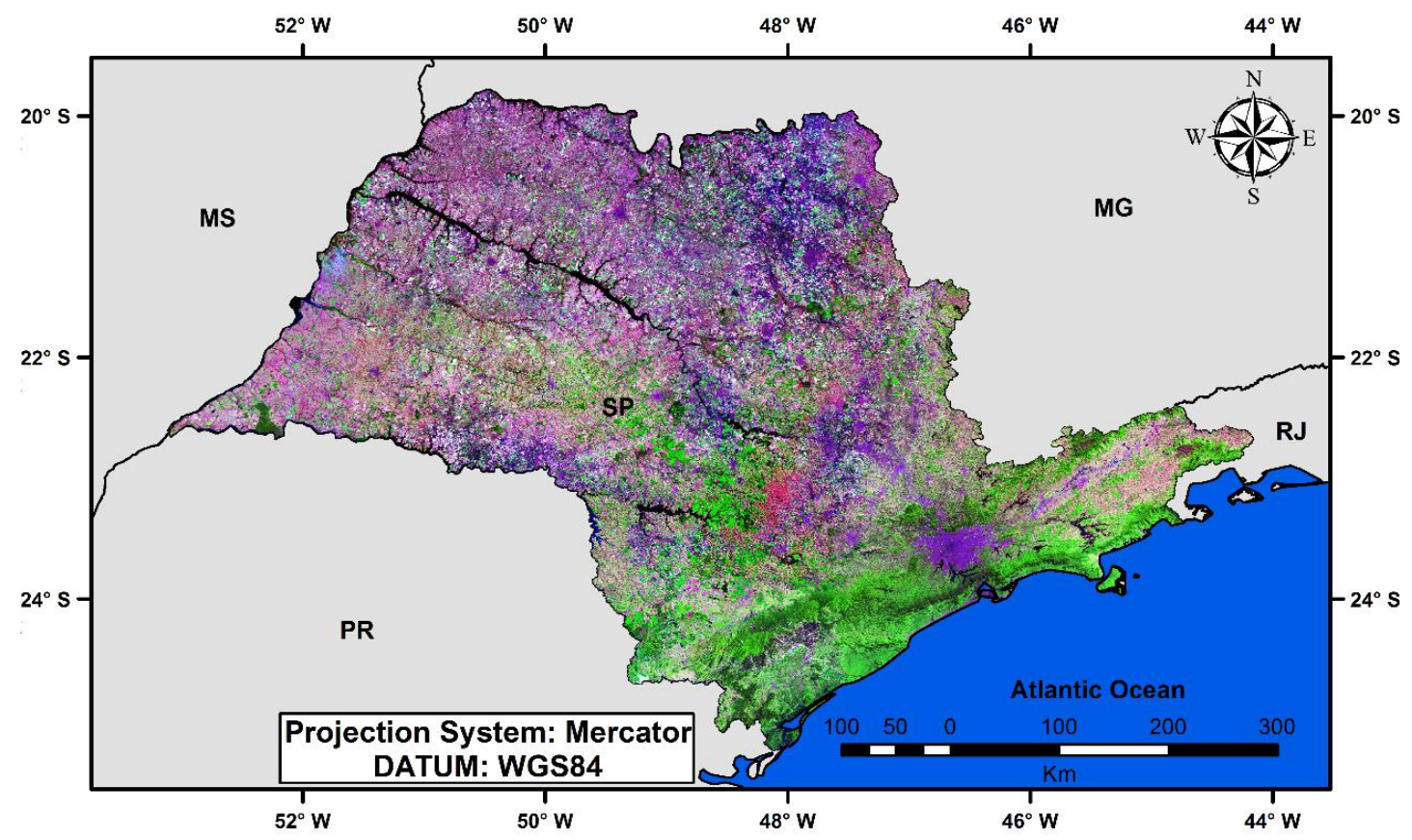

Figure 01 - Location of the study area, the state of São Paulo (Brazil). TM/Landsat-5 images mosaic (2010), R5G4B3 composition. 
Due to interest in reducing the dependency on fossil fuels and new global environmental concerns, the use of ethanol produced from sugarcane is taking a leading role in power generation (RUDORFF et al, 2010). In Brazil, the use of ethanol increased especially after 2003 with the popularization of flex-fuel cars, which stimulates the expansion of sugarcane cultivation and caused a rapid expansion of this crop over the past decade (AGUIAR et al, 2011).

During sugarcane harvest, it is common to use straw burning to facilitate harvesting. However, considering the negative impacts of biomass burning over the environment and over health, the Law 11,241, approved in São Paulo state in 2002, established a schedule for banning pre-harvest burning, setting as deadline the year 2021 for mechanizable areas (slope $\leq 12 \%$ ) and 2031 for non-mechanizable areas (slope > 12\%) (Bordonal et al., 2013). In order to speed up the end of pre-harvest burning, the Department of Environment of São Paulo and the Sugarcane Industry Union (UNICA) signed in August 2007 a letter of intentions named Green Ethanol Protocol (AGUIAR et al., 2011). Green Ethanol
Protocol established that the practice of preharvest burning should be gradually reduced until complete elimination in 2014 for mechanizable areas and in 2017 for non-mechanizable areas (BORDONAL et al., 2013).

As shown in Figure 2(a), the percentage of pre-harvest burning gradually decreased between 2006 and 2012, period when the information of the type of harvest produced by the CANASAT Project for São Paulo state is available (CANASAT, 2016). In 2006, 65.8\% of the harvest in São Paulo state used pre-harvest burning, with a decrease over the years, reaching $27.4 \%$ in 2012.

Despite the decrease in percentage, there is an increase of $16 \%$ in the total area harvested using pre-harvest burning for 2010 when compared to 2009 (Figure 2(b)), explained by the expansion of the crop and the drought in 2010 (AGUIAR et al., 2011). Still according to Aguiar et al. (2011), the decrease in pre-harvest burning is related to the establishment of the Green Ethanol Protocol, a positive initiative in encouraging the adoption of green harvest, especially in areas of expansion of the crop. 

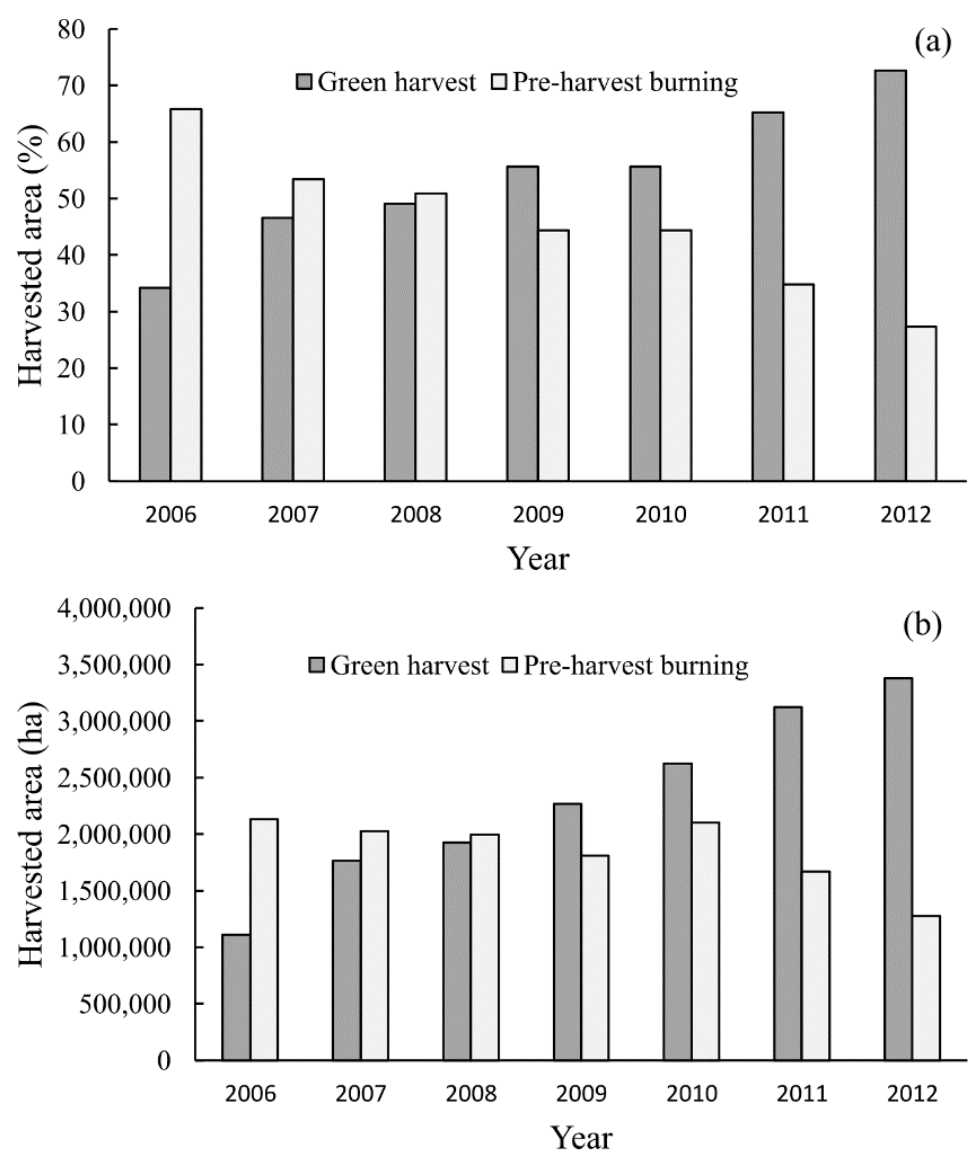

Figure 02 - Total and percentage area of green harvest and pre-harvest burning in São Paulo state between 2006 and 2012. Source: Canasat (2016).

\section{2}

\section{CANASAT PROJECT DATA}

Considering the rapid expansion of sugarcane and the favorable characteristics of the crop to be monitored using satellite images, National Institute for Space Research (INPE) started in 2003 the CANASAT Project, which annually maps sugarcane cultivated area in South-Central Brazil (Rudorff et al., 2010). CANASAT Project maps sugarcane cultivation areas through digital classification and visual interpretation of orbital remote sensing images using a wide range of sensors, such as Thematic Mapper (TM), Linear Imaging Self-Scanner (LISSIII), Enhanced Thematic Mapper Plus (ETM+), and Couple Charged Device (CCD) (RUDORFF et al., 2010)

Between 2006 and 2012, CANASAT Project also provided data about the type of harvest in São Paulo state, allowing the monitoring of green harvest and pre-harvest burning and evaluating the effectiveness of the
Green Ethanol Protocol (AGUIAR et al., 2011). CANASAT Project type of harvest maps were used to determine if the fires detected by the active fire products occurred in areas that used preharvest burning.

\subsection{ACTIVE FIRE PRODUCTS}

In this study, two sensors that estimate the FRP in the active fire product were used: Moderate Resolution Imaging Spectroradiometer (MODIS) and Spinning Enhanced Visible and Infrared Imager (SEVIRI).

MODIS sensor is onboard Terra and Aqua satellites in polar orbit 705 kilometers $(\mathrm{km})$ above the surface, operating in 36 spectral channels at wavelengths ranging from $0.4 \mu \mathrm{m}$ to $14.4 \mu \mathrm{m}$ with spatial resolution of 250,500 or 1.000 meters, depending on the product, and temporal resolution of 1 to 2 days. This sensor is configured to provide data about the dynamics of the biosphere in order to understand the 
processes caused by human activities or by nature occurring in the surface of the earth, in the oceans, and in the lower atmosphere (JUSTICE et al., 2002).

MODIS time of acquisition over a surface area varies according to the platform. While Terra platform (products designated with the abbreviation MOD) crosses the Equator in its downward orbit at 10:30 and 22:30, Aqua platform (products designated with the abbreviation MYD) in its upward orbit crosses the Equator at 13:30 and 01:30, enabling, thereby, 4 daily imaging surveys from one point of the surface (GIGLIO, 2003). MODIS active fire products (MOD14 and MYD14), available by the database Level 1 and Atmosphere Archive and Distribution System (LAADS Web), provide the location of fires based on the emission of targets at wavelengths centered in $4 \mu \mathrm{m}$ and $11 \mu \mathrm{m}$ with spatial resolution of $1 \mathrm{~km}$ (ICHOKU et al., 2012).

SEVIRI sensor is onboard the second generation of geostationary satellite METEOrological SATellite (METEOSAT) 36,000 km above the surface. The sensor consists of an imaging radiometer that collects data every 15 minutes, making it ideal for the study of dynamic phenomena such as fires. SEVIRI sensor is centered over Africa and Europe and operates in 12 spectral channels in spectral wavelengths in the visible, near infrared and thermal infrared, presenting an average spatial resolution of $6 \mathrm{~km}$ for Brazil (ROBERTS and WOOSTER, 2008).

SEVIRI active fire product (FRP-PIXEL) is available by the Land Surface Analysis Satellite Aplications Facility (LAS SAF) and provides 14 variables, including the spatial location of fires, FRP and time of acquisition.

\subsection{ACTIVE FIRE PRODUCTS PRE- PROCESSING}

Considering the different active fire products used, each one needs a pre-processing that begins converting the original data format (Hierarchical Data Format, or HDF) in American Standard Code for Information Interchange (ASCII) format containing the same information of the original products.
During MOD14 and MYD14 products pre-processing, pixels of low reliability (less than $30 \%$ ) were eliminated, and then the area of each pixel containing fires was calculated according to Equation 4, proposed by Ichoku and Kaufman (2005).

$A_{\text {rad }}=\left\{R_{e} S \cdot\left[\frac{\cos \theta}{\sqrt{\left(R_{e} / r\right)^{2}-\operatorname{sen}^{2} \theta}}-1\right]\right\} *\left\{\left[r . S \cdot\left(\cos \theta-\sqrt{\left(R_{e} / r\right)^{2}}-\operatorname{sen}^{2} \theta\right)\right]\right\}$

where Areal represents the real area of the pixel $(\mathrm{km}), \mathrm{Re}$ is the radius of the Earth $(6378.13 \mathrm{~km}), \mathrm{r}$ represents the sum of $R_{e}$ and the altitude of the sensor (705 km for MODIS), $S$ is the ratio between the average spatial resolution of one pixel of MODIS at nadir ( $1 \mathrm{~km})$ and the altitude of the sensor, and $\theta$ represents the viewing angle.

Moreover, considering the geometrical characteristics of MODIS sensor, operating with an imaging angle of up to \pm 55 degrees, the bowtie effect, which consists in the overlap of the area of a pixel due to the increase in the viewing angle, should be corrected. The main problem of the bow-tie effect in estimating FRP is the repetition of a pixel with fire in adjacent pixels, being that fires in pixels off-nadir can be represented in two or even three adjacent pixels (FREEBORN et al., 2008).

There are adjustments developed to minimize the replication of fires in adjacent pixels and to correct the bow-tie effect in FRP estimated by MOD14 and MYD14, such as those proposed by Freeborn et al. (2011) and Kaiser et al. (2012). The correction of bow-tie effect was realized from Equation 5, proposed by Kaiser et al. (2012), where FRP estimated by MODIS is corrected by the square cosine of the viewing angle.

$F R P=F R P_{M O D I S} * \cos ^{2} \theta$

where FRP (MW) represents the bow-tie adjusted FRP, FRPMODIS (MW) is the original FRP from MOD14 and MYD14 fire products and $\theta$ is the viewing angle.

In the end of the pre-processing for MOD14 and MYD14 an ASCII format file was 
generated containing the following data about the fires detected by MODIS: latitude, longitude, FRP, time of acquisition and pixel area.

For FRP-PIXEL, after converting original HDF format to ASCII files, all pixels presenting reliability lower than $30 \%$ were excluded. The next step of pre-processing consisted on correcting FRP estimated by FRP-PIXEL using FRP estimates from MODIS, once FRP estimated by MODIS is considered a good reference due to the spatial resolution of MOD14 and MYD14 (ROBERTS and WOOSTER, 2008).

On average, FRP derived from SEVIRI is underestimated between $30 \%$ and $50 \%$ when compared to MODIS (ROBERTS and WOOSTER, 2008), therefore, FRP estimated by SEVIRI was corrected in $40 \%$ of the monthly average of MODIS FRP estimates. In their study, Roberts and Wooster (2008) compared FRP derived from MODIS and SEVIRI sensors for approximately 300 simultaneous fires, and concluded that the FRP estimates between $40 \mathrm{MW}$ and $3000 \mathrm{MW}$ have good agreement, however, FRP derived from SEVIRI is overestimated below $40 \mathrm{MW}$ and underestimated above $3000 \mathrm{MW}$ when compared to MODIS. In the end of the preprocessing, an ASCII format file was generated containing the same data described for MOD14 and MYD14.

\subsection{BIOMASS BURNING AND $\mathrm{CO}_{2}$ EMISSON ESTIMATES}

Considering that the active fire products used are global (MOD14 and MYD14) or for South America (FRP-PIXEL) and the study aims to quantify $\mathrm{CO}_{2}$ emissions associated with sugarcane pre-harvest burning, only fires occurred in areas mapped as pre-harvest burning by the CANASAT project in São Paulo state were considered. For the years 2013 and 2014 the thematic map used was corresponded to 2012, because this is the last mapping provided by the CANASAT project.

However, there are uncertainties regarding the accurate spatial location of the data used due to the characteristics of the sensor systems previously presented, therefore, it was decided to create an $8 \mathrm{~km}$ buffer around the areas of pre-harvest burning defined by the thematic mapping of CANASAT project. The distance of the buffer was defined as a pixel offset in relation to the lowest spatial resolution of the active fire products used $(8 \mathrm{~km}$ for FRPPIXEI, which can reach this spatial resolution in the West of São Paulo state).

In sequence, $\mathrm{CO}_{2}$ emission rate was estimated using Equation 6:

$C \mathrm{O}_{2_{\text {Rate }}}=\mathrm{FRP}^{*} \mathrm{BBC} * \mathrm{EF}^{\left[\mathrm{CO}_{2}\right]}$

where $\mathrm{CO}_{2}$ Rate represents the $\mathrm{CO}_{2}$ emission rate $(\mathrm{g}$ $\left.\mathrm{s}^{-1}\right), \mathrm{FRP}$ is the fire radiative power (MW), BBC represents the biomass burning coefficient $(\mathrm{kg}$ $\left.\mathrm{MJ}^{-1}\right)$, and $\mathrm{EF}\left[\mathrm{CO}_{2}\right]$ is the emission factor for $\mathrm{CO}_{2}$ (g $\left.\mathrm{kg}^{-1}\right)$.

It is important to point out that the BBC, which represents the amount of biomass burned $(\mathrm{kg})$ for each MJ of energy released, is specific for each type of vegetation. This coefficient is available in literature for a wide range of vegetation types (e.g. WOOSTER et al., 2005; FREEBORN et al., 2008; PEREIRA et al., 2012), however, the $B B C$ used $\left(0.57 \mathrm{~kg} \mathrm{MJ}^{-1}\right)$ was extracted from Mataveli et al. $(2015, a)$, which estimated this coefficient for sugarcane preharvest burning from a small-scale combustion experiment. Regarding the $\mathrm{EF}\left[\mathrm{CO}_{2}\right]$, which represents the mass of $\mathrm{CO}_{2}(\mathrm{~g})$ emitted for each $\mathrm{kg}$ of biomass burned, the one used $\left(1,303 \mathrm{~g} \mathrm{~kg}^{-1}\right)$ was extracted from França et al. (2013), which estimated the emission factors for sugarcane preharvest burning from a small-scale combustion experiment.

Finally, total annual $\mathrm{CO}_{2}$ emissions were estimated integrating $\mathrm{CO}_{2}$ Rate in an $8 \mathrm{~km}$ regular grid using the time of acquisition information available in the active fire products, as shown in Equation 7:

$\mathrm{CO}_{2}($ lon, lat $)=\frac{1}{2} * \sum_{t=1}^{n}\left(\mathrm{CO}_{2_{\text {Rate }} n}+\mathrm{CO}_{2_{\text {Rate }} n+1}\right) *\left(t_{n+1}-t_{n}\right)$

where $\mathrm{CO}_{2}$ (lon,lat) represents the total $\mathrm{CO}_{2}$ emitted in each cell of the $8 \mathrm{~km}$ regular grid $(\mathrm{g})$, $\mathrm{CO}_{2}$ Rate represents the $\mathrm{CO}_{2}$ emission rate in the times $n$ and $n+1\left(\mathrm{~g} \mathrm{~s}^{-1}\right)$, and $t$ is the time of acquisition of each active fire product used (s). 


\section{RESULTS AND DISCUSSIONS}

Figure 3 shows total number of fires detected by MODIS and SEVIRI sensors in sugarcane crop areas of São Paulo state between 2008 and 2014. Despite the differences between total fires for each sensor, due to the characteristics of the sensors presented above, the same pattern was found for both sensors. Total fires decreased from 2008 to 2009, increased to the maximum in 2010, decreased from 2011 to 2013 and increased again in 2014.

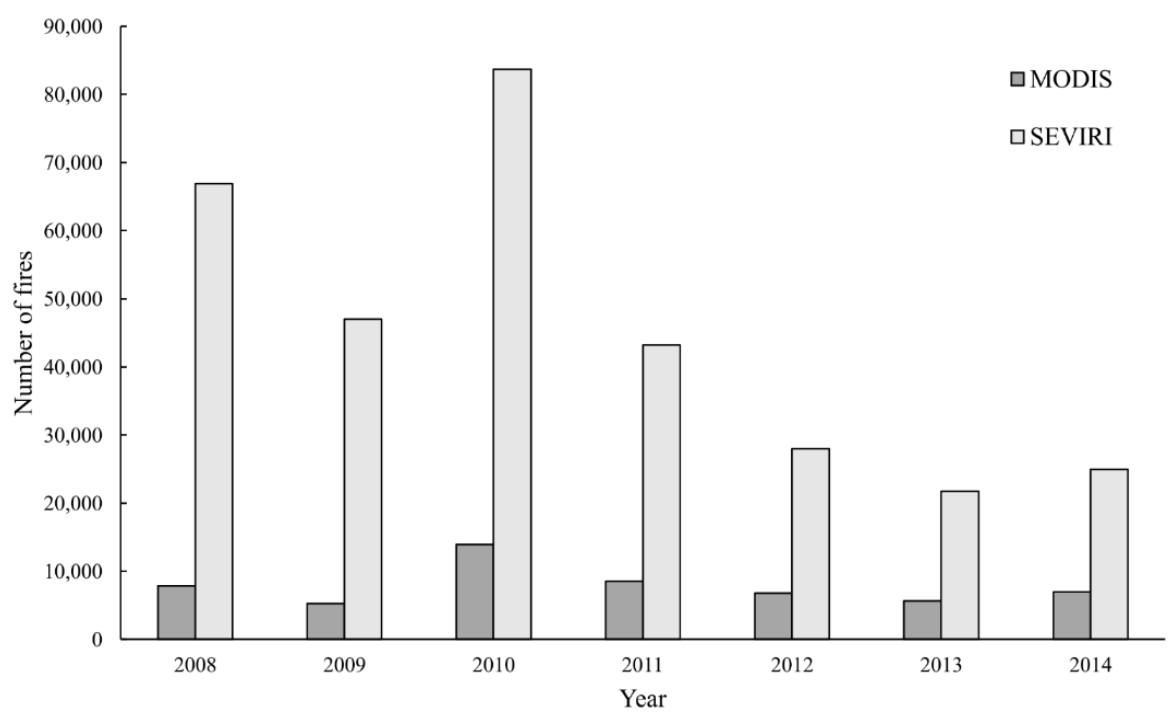

Figure 03 - Total number of fires detected by MODIS and SEVIRI sensors in sugarcane crop areas of São Paulo state between 2008 and 2014.

In 2010, total number of fires considering both sensors was $86 \%$ higher than in 2009. This result was expected, once areas using pre-harvest burning in São Paulo state in 2010 were the largest since 2006 (Canasat, 2016), explained by the expansion of the crop and by the drought between May and August (period of sugarcane harvest), favoring the occurrence of fires due to the lack of rain and low humidity (AGUIAR et al., 2011). The drought also explains the increase of fires in 16\% between 2013 and 2014, once 2014 had one of the most severe droughts in South-Eastern Brazil (COELHO et al., 2016). It was expected a higher increase between 2013 and 2014 considering the drought in 2014, as occurred between 2009 and 2010, however, the deadline for ending pre-harvest burning in mechanizable areas established by the Green Ethanol Protocol contributed for the increase in only $16 \%$ between these two years.

For SEVIRI active fire product, total fires in 2008 were below expected, which can be explained by the fact that FRP-PIXEL started providing data in April of 2008, therefore, fires between January and March of 2008 were not detected. Despite this, SEVIRI sensor detected approximately 5.7 times more fires than MODIS during the years analyzed. Fire detection algorithm of SEVIRI and its temporal resolution of 15 minutes explain this difference, once the time required for the fire to consume a plot of sugarcane of 5 ha is about 10 to 15 minutes (MARINHO and KIRCHHOFF, 1991).

Regarding biomass burning, burned biomass estimation ranged significantly from 2008 to 2014: total annual burned biomass during the 7 years was, respectively, 65, 39.8, 81.9, 35.2, 19.5, 14.8, and 3.39 Gigagrams (Gg). Highest annual estimate for a grid cell considering the period between 2008 and 2014 was, respectively, 13,380, 13,041, 97,569, 17,544, 11,170, 10,816, and 5,408 $\mathrm{kg} \mathrm{km}^{-2}$. However, regarding the spatial distribution of biomass burning, the same pattern was found for all years 
analyzed, as shown in Figure 4, which represents the spatial distribution of biomass burning in sugarcane crop areas for 2010. As expected, biomass burning was concentrated in the Northern region of the state, where there is most of the cropped area, and where some of the municipalities with the largest cropped area are located, such as Morro Agudo, Barretos and Guaíra (A, B, and C in Figure 4, respectively) (Canasat, 2016). It is also worth mentioning two other areas where biomass burning was high: the Central region of the state (D in Figure 4 ), also

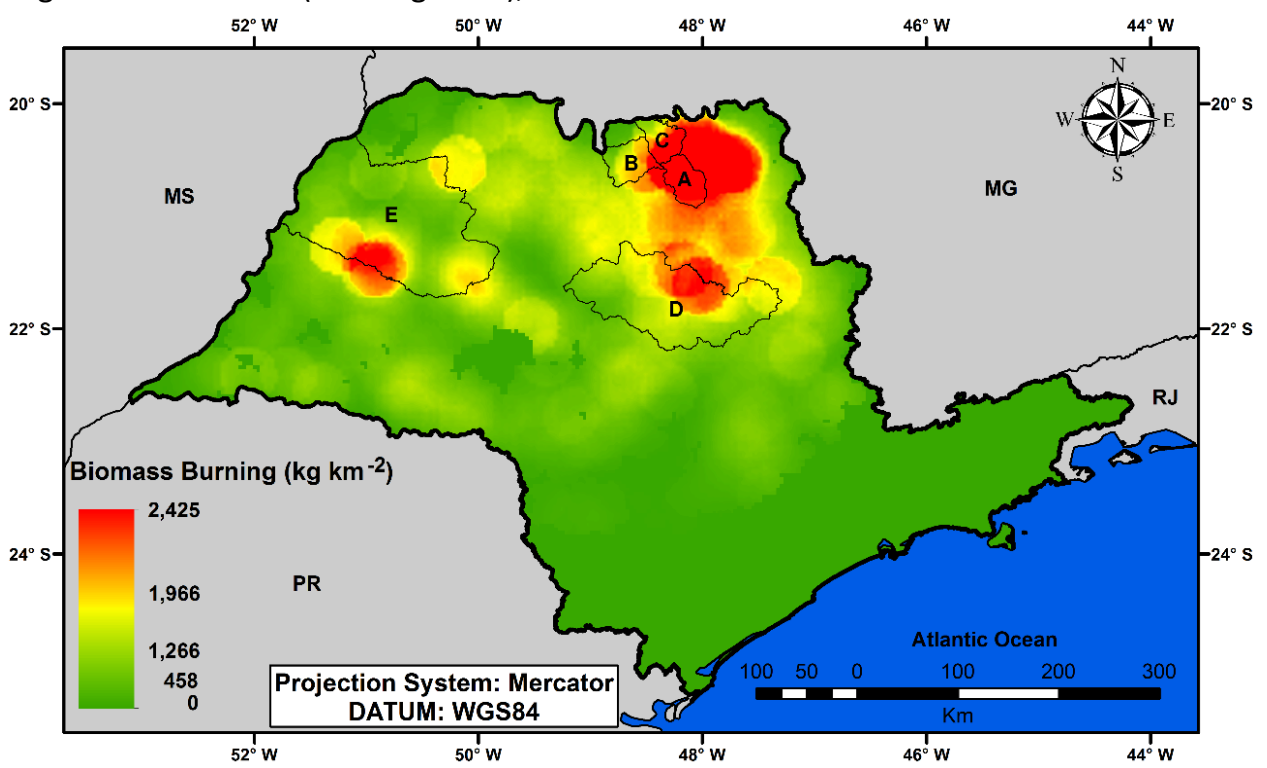

Figure 04 - Spatial distribution of biomass burning associated with sugarcane pre-harvest burning in São Paulo state for 2010, highlighting the municipalities of Morro Agudo (A), Barretos (B),

The decrease in the number of fires and in biomass burning affected the emissions of $\mathrm{CO}_{2}$, which decreased drastically from 2008 to 2014, as shown in Figure 5. traditional in sugarcane cultivation, and the Araçatuba region ( $E$ in Figure 4), where the highest estimate of biomass burning for a grid cell was found during the period analyzed $(97,569$ $\mathrm{kg} \mathrm{km}^{-2}$, for 2010). Regarding the expansion of sugarcane crop, it is taking place in the Western region, however, new areas are emerging according to the impositions defined by the Green Ethanol Protocol, and, consequently, sugarcane pre-harvest burning is not usual.

\footnotetext{
Guaíra (C), and the regions Central (D) and Araçatuba (E).
} 


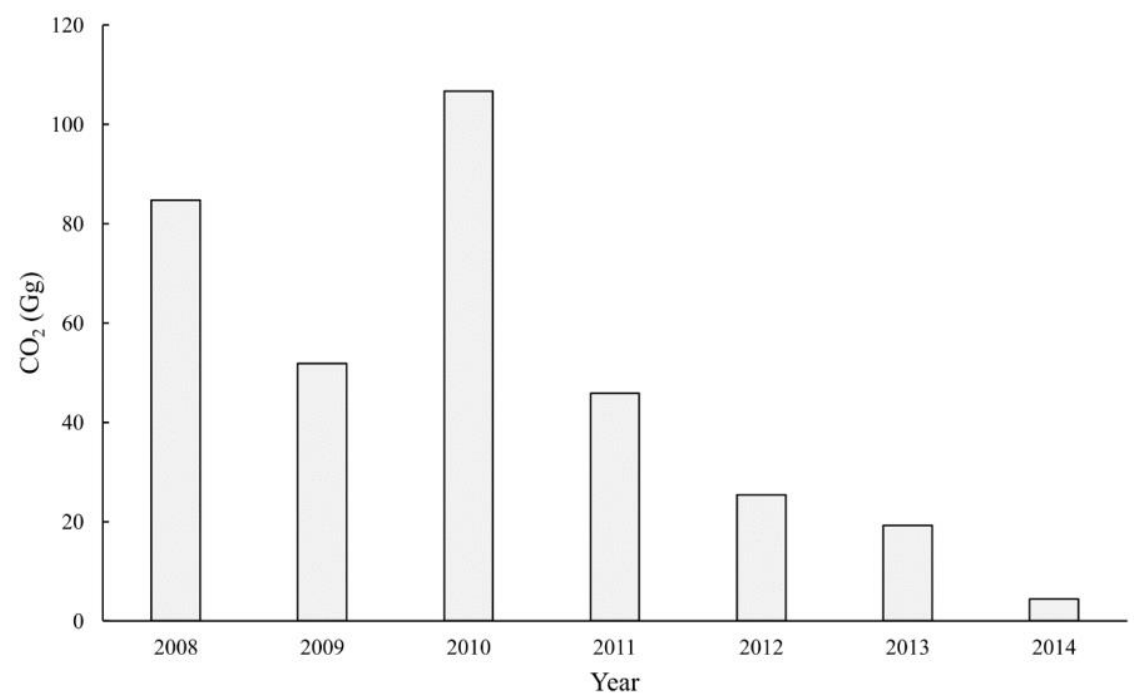

Figure 05 - Annual $\mathrm{CO}_{2}$ emitted by sugarcane pre-harvest burning in São Paulo state between 2008 and 2014.

Annual emissions of $\mathrm{CO}_{2}$ from sugarcane pre-harvest burning during 2008 to 2014 were, respectively, $84.70,51.86,106.67,45.87,25.37$, 19.27, and $4.42 \mathrm{Gg}$. In 2014, total emissions of $\mathrm{CO}_{2}$ from sugarcane pre-harvest burning represented approximately $5.2 \%$ of total emissions for 2008, even with FRP-PIXEL providing starting in April of 2008, and represented $4.1 \%$ of the emissions for 2010, when $\mathrm{CO}_{2}$ emissions were the highest. These results agree with those found by Mataveli et al. (2015, b), who estimated $\mathrm{CO}_{2}$ emissions from sugarcane pre-harvest burning between 2009 and 2013.

It is worth mentioning the decrease in total emissions between 2013 and 2014 (about $77 \%$ ) despite the increase of $16 \%$ in the number of fires. This result indicates that in 2014 FRP detected by the active fire products was lower when compared to the other years analyzed; FRP is an estimate directly dependent on the fire temperature and the active fire area, therefore, this result suggest that fires were less intense and burned area was smaller in 2014, causing lower emission of $\mathrm{CO}_{2}$. Moreover, still considering the suggestion that fires were smaller and less intense in 2014, it should be mentioned that small fires are more difficult to be detected by orbital remote sensing active fires products, therefore, omission errors may have occurred in this year.

Results found show the efficiency of Green Ethanol Protocol for reducing emissions from pre-harvest burning, and even greater reductions are expected until 2017, when preharvest burning must end in non-mechanizable areas. In these areas, where the use of harvest machinery is not possible, land use change will be necessary. However, it is accepted that even restricted by law fires in sugarcane areas will not be totally eliminated, once fires could start from accidents, natural causes, such as lightning, and even criminally. In addition, favorable environmental conditions increase the occurrence of fires and difficult their control, as occurred in 2010.

Moreover, according to Aguiar et al. (2011), this issue deserves further studies to fully understand environmental benefits from Green Ethanol Protocol. Prohibiting pre-harvest burning adds new sources of emissions of greenhouse gases, such as fossil fuels, once harvest machinery use increases and transport from cropped area to the industry also increases, because the volume to be transported without burning is larger. 


\section{CONCLUSIONS}

Considering the results found, the use of active fire products derived from orbital sensors and the use of the method based of Fire Radiative Power to estimate emissions from biomass burning are efficient. However, despite the method used presents the best performance when compared to other methods according to literature, there are uncertainties, just like any other estimate from orbital remote sensing. Therefore, future efforts should focus of validating the results found.

As expected, SEVIRI based active fire product detected more fires than MODIS active fire products, once it has a higher temporal resolution. Fires were higher in 2010, explained by the drought in this year and the expansion of the crop. Spatially, biomass burning was higher in the Northern of São Paulo state, where most of the sugarcane cultivation is located. It was detected more than $13,000 \mathrm{~kg} \mathrm{~km}^{-2}$ in a grid cell for 2010.

Regarding total annual emissions of $\mathrm{CO}_{2}$ from sugarcane pre-harvest burning, it is possible to identify a significant reduction in $\mathrm{CO}_{2}$ emissions. Between 2013 and 2014 CO $_{2}$ emissions drastically decreased despite the increase in the number of fires, even considering the drought in 2014.It is expected decreasing emissions in future years, once pre-harvest burning in nonmechanizable areas must end in 2017. Thus, the adoption of Green Ethanol Protocol seems to be effective for reducing emissions from pre-harvest burning and can be used as example for developing a national law to end pre-harvest burning.

Finally, future studies should analyze the contribution of new sources of $\mathrm{CO}_{2}$ that are emerging, such as the increasing use of fossil fuels by harvesting machines, to really evaluate the effectiveness of Green Ethanol Protocol.

\section{ACKNOWLEDGMENTS}

The authors would like to thank the National Counsel of Technological and Scientific Development (CNPq, Process 455097/2013-5) and the Coordination for the Improvement of
Higher Education Personnel (CAPES, Grant Number 6123/2015-05) for the financial support.

\section{REFERENCES}

AGUIAR, D. A.; RUDORFF, B. F. T.; ADAMI, M.; SHIMABUKURO, Y. E. Imagens de sensoriamento remoto no monitoramento da cana-de-açúcar. Engenharia Agrícola, Jaboticabal, v. 29, p. 440451, 2009.

AGUIAR, D. A.; RUDORFF, B. F. T.; SILVA, W. F. Monitoramento do modo de colheita da cana-deaçúcar no Estado de São Paulo - Brasil por meio de imagens de sensores orbitais em dois anossafra. Revista SELPER, Bogotá, v. 30, p. 34-43, 2010.

AGUAIR, D. A.; RUDORFF, B. F. T.; SILVA, W. F.; ADAMI, M.; MELLO, M. P. Remote sensing images in support of environmental protocol: monitoring the sugarcane harvest in São Paulo, Brazil. Remote Sensing, Basel, v.3, p. 2682-2703, 2011.

ANDREAE, M. O.; MERLET, P. Emission of trace gases and aerosols from biomass burning. Global Biogeochemical Cycles, Washington, v.4, p. 955966, 2001.

BORDONAL, R. O.; FIGUEIREDO, E. B.; AGUIAR, D. A.; ADAMI, A.; RUDORFF, B. F. T.; LA SCALA, N. Greenhouse gas mitigation potential from green harvested sugarcane scenarios in São Paulo State, Brazil. Biomass \& Energy, Amsterdam, v. 59, p. 195-207, 2013.

BURLING, I. R.; YOKELSON, R. J.; GRIFFITH, D. W. T.; JOHNSON, T. J.; VERES, P.; ROBERTS, J. M.; WARNEKE, C.; URBANSKI, S. P.; REARDON, J.;

WEISE, D. R.; HAO, W. M.; DE GOUW, J. Laboratory measurements of trace gas emissions from biomass burning of fuel types from the Southeastern and Southwestern United States. Atmospheric Chemistry and Physics Discussion, Gottingen, v. 10, p. 16425-16473, 2010.

CANASAT. Sugarcane Crop Mapping in Brazil by Earth Observing Satellite Images: Maps and Graphs. São José dos Campos: INPE, 2016. Available in: http://www.dsr.inpe.br/laf/canasat/en/. Access on 14 mar. 2016.

COELHO, C. A. S.; DE OLIVEIRA, C. P.; AMBRIZZI, T.; REBOITA, M. S.; CARPENEDO, C. B.; CAMPOS, 
J. L. P. S.; TOMAZIELLO, A. C. N.; PAMPUCH, L. A.; CUSTÓDIO, M. D. S.; DUTRA, L. M. M.; DA ROCHA, R. P.; REHBEIN, A.: The 2014 southeast Brazil austral summer drought: regional scale mechanisms and teleconnections. Climate Dynamics, New York, v. 46, p. 3737-3752, 2016. FORSTER, P.; RAMASWAMY, V.; ARTAXO, P.; BERNTSEN, T.; BETTS, R.; FAHEY, D. W.; HAYWOOD, J.; LEAN, J.; LOWE, D. C.; MYHRE, G.; NGANGA, J.; PRINN, R.; RAGA, G.; SCHULZ, M.; VAN DORLAND, R. Changes in Atmospheric Constituents and in Radiative Forcing. In: SOLOMON, S. D.; QIN, M.; MANNING, Z.; CHEN, M.; MARQUIS, K. B.; AVERYT, M. T.; MILLER, H. L (Ed.).Climate Change 2007: The Physical Science Basis. Cambridge: Cambridge University, 2007. p. 129-234.

FRANÇA, D. A.; LONGO, K. M.; NETO, T. G. S.; SANTOS. J. C.; FREITAS, S. R.; RUDORFF, B. F. T.; CORTEZ, E. V.; ANSELMO, E; CARVALHO JUNIOR, J. A. Pre-harvest sugarcane burning: determination of emission factors through laboratory measurements. Atmosphere, Basel, v. 3, p. 164-180, 2012.

FREEBORN, P. H.; WOOSTER, M. J.; HAO, W. M.; RYAN, C. A.; NORDGREN, B. L.; BAKER, S. P.; ICHOKU, C. Relationships between energy release, fuel mass loss, and trace gas and aerosol emissions during laboratory biomass fires. Journal of Geophysical Research, Washington, v. 113, p. 1301-1318, 2008.

FREEBORN, P. H.; WOOSTER, M. J.; ROBERTS, G. Addressing the spatiotemporal sampling design of MODIS to provide estimates of the fire radiative energy emitted from Africa. Remote Sensing of Environment, Amsterdam, v. 115, p. 475-498, 2011.

GIGLIO, L.; KENDALL, J.; MACK, R. A multi-year active fire dataset for the tropics derived from the TRMM VIRS. International Journal of Remote Sensing, London, v. 24, p. 4505-4525, 2003.

HANTSON, S.; PADILLA, M.; CORTI, D.; CHUVIECO, E. Strengths and weaknesses of MODIS hotspots to characterize global fire occurrence. Remote Sensing of Environment, Amsterdam, v.131, p. 152-159, 2013.
ICHOKU, C.; KAUFMAN, Y. J. A method to derive smoke emission rates from MODIS fire radiative energy measurements. IEEE Transactions on Geoscience and Remote Sensing, New York, v. 43, p. 2636-2649, 2005.

ICHOKU, C.; GIGLIO, L.; WOOSTER, M. J.; REMER, L. Global characterization of biomass-burning patterns using satellite measurements of fire radiative energy. Remote Sensing of Environment, Amsterdam, v. 112, p. 2950-2962, 2008.

ICHOKU, C.; KAHN, R.; CHIN, M. Satellite contributions to the quantitative characterization of biomass burning for climate modeling. Atmospheric Research, Amsterdam, v.111, p. 128, 2012.

ICHOKU, C.; ELLISON, L. Global top-down smokeaerosol emissions estimation using satellite fire radiative power measurements. Atmospheric Chemistry and Physics, Gottingen, v. 14, p. 66436667, 2014.

JUSTICE, C. O.; GIGLIO, L.; KORONTZI, S.; OWENS, J.; MORISETTE, J. T.; ROY, D. The MODIS fire products. Remote Sensing of Environment, Amsterdam, v. 83, p. 244-262, 2002.

KAISER, J. W.; HEIL, A.; ANDREAE, M. O.; BENEDETTI, A.; CHUBAROVA, N.; JONES, L.; MORCRETTE. J. J.; RAZINGER, M.; SCHULTZ, M. G.; SUTTIE, M.; VAN DER WERF, G. R. Biomass burning emissions estimated with a global fire assimilation system based on observed fire radiative power. Biogeosciences, Gottingen, v.9, p. 527-554, 2012.

LEVINE, J. S. Biomass burning and the production of greenhouse gases. In: ZEPP, R. G. (Ed.). Climate Biosphere Interaction: Biogenic Emissions and Environmental Effects of Climate Change. Ney York: John Wiley and Sons, 1994. p. 1-15.

MARINHO, E. V. A.; KIRCHHOFF, V. W. J. H. Projeto fogo: um experimento para avaliar efeitos das queimadas de cana-de-açúcar na baixa atmosfera. Revista Brasileira de Geofísica, Rio de Janeiro, v.9, p.107-119, 1991.

MATAVELI, G. A. V.; PEREIRA, G.; MORAES, E. C.; OLIVEIRA, B. S.; CARDOZO, F. S. Relação entre o ângulo de visada e a estimativa da Potência 
Radiativa do Fogo. Boletim de Ciências Geodésicas, Curitiba, v. 21, p. 371-388, 2015 a.

MATAVELI, G. A. V.; PEREIRA, G.; OLIVEIRA, B. S.; MORAES, E. C. Uso da Potência Radiativa do Fogo para estimar a biomassa queimada e as emissões de $\mathrm{CO}_{2}$ associadas à queimada pré-colheita da cana-de-açúcar no estado de São Paulo. In: SIMPÓSIO BRASILEIRO DE SENSORIAMENTO REMOTO, XVII, 2015 b, João Pessoa: INPE, p. 1508-1515.

MOUILLOT, F.; SCHULTZ, M. G.; YUE, C.; CADULE, P.; TANSEY, K.; CIAIS, P.; CHUVIECO, E. Ten years of global burned area products from spaceborne remote sensing-A review: Analysis of user needs and recommendations for future developments. International Journal of Applied Earth Observation and Geoinformation, Amsterdam, v. 26, p. 64-79, 2014.

PEREIRA, G.; CARDOZO, F. S.; SILVA, F. B.; MORAES, E. C.; FERREIRA, N. J.; FREITAS, S. R.; SHIMABUKURO, Y. E.; BREUNIG, F. M.; VIANA, D. R. Determinação e modelagem da taxa de consumo de biomassa queimada. Revista Brasileira de Meteorologia, Rio de Janeiro, v.27, p. 13-22, 2012.

PEREIRA, G.; CARDOZO, F. S.; SHIMABUKURO, Y. E.; MORAES, E. C.; FREITAS, S. R. Estimativa da área de fogo ativo a partir da potência radiativa do fogo. Revista Brasileira de Cartografia, Brasília, v.64, n.4, p. 419-428, 2012.

PEREIRA, G.; SIQUEIRA, R.; ROSÁRIO, N. E.; LONGO, K. L.; FREITAS, S. R.; CARDOZO, F. S.; KAISER, J. W.; WOOSTER, M. J. Assessment of fire emissions inventories during the South American Biomass Burning Analysis (SAMBBA) experiment. Atmospheric Chemistry and Physics, Gottingen, v. 1, p. 1-23, 2016.

ROBERTS, G.; WOOSTER, M. J.; PERRY, G. L. W.; DRAKE, N.; REBELO, L. M.; DIPOTSO, F. Retrieval of biomass combustion rates and totals from fire radiative power observations: Application to southern Africa using geostationary SEVIRI imagery. Journal of Geophysical Research, Washington, v. 110, p. 1-20, 2005.

ROBERTS, G.; WOOSTER, M. J. Fire detection and fire characterization over Africa using Meteosat SEVIRI. IEEE Transactions on Geoscience and
Remote Sensing, New York, v. 46, p. 1200-1218, 2008.

RUDORFF, B. F. T.; AGUIAR, D. A.; SILVA, W. F.; SUGAWARA, L. M.; ADAMI, M.; MOREIRA, M. A. Studies on the rapid expansion of sugarcane for ethanol production in São Paulo State (Brazil) using Landsat data. Remote Sensing, Basel, v.2, p. 1057-1076, 2010.

SEILER, W.; CRUTZEN, P.J. Estimates of gross and net fluxes of carbon between the biosphere and the atmosphere from biomass burning. Climatic Change, Berlin, v. 2, n. 1, p. 207-248, 1980.

SHIMABUKURO, Y. E.; PEREIRA, G.; CARDOZO, F. S.; STOCKLER, R.; FREITAS, S. R.; COURA, S. M. C. Biomass burning emission estimation in Amazon tropical forest. In: SEGURA, D. A.; DI BELLA, C. M.; STRASCHNOY. J. V. (Org.). Earth Observation of Ecosystem Services. Oxford: Taylor \& Francis, 2013. 7, 112-130.

WOOSTER, M. J. Small-scale experimental testing of fire radiative energy for quantifying mass combusted in natural vegetation fires. Geophysical Research Letters, Washington, v.29, n.21, p. 23-1-23-4, 2002.

WOOSTER, M. J.; ROBERTS, G.; PERRY, G.; KAUFMAN, Y. J. Retrieval of biomass combustion rates and totals from fire radiative power observations: calibration relationships between biomass consumption and fire radiative energy release. Journal of Geophysical Research, Washington, v.110, p. 83-107, 2005. 